DOI: $10.53469 /$ jissr.2021.08(09).11

\title{
Indian Citizenship Amendment Debate
}

\author{
Rinal Rose Pauly \\ B. Com L. L. B, CSI College for Legal Studies Kanakkary, Kottayam, Kerala, India
}

"Every citizen of India must remember that he is an Indian and he has every right in this country but with certain duties"-

Sardar Vallabhbhai.

\section{Introduction}

Citizenship signifies the relation between individual and state. Citizens are full members of the Indian state and owe allegiance to it. They enjoy all civil and political rights and they have also certain duties. There are two well known principle for the grant of citizenship, 'jus soli' and 'jus sanguine. 'jus soli' confers citizenship on the basis of place of birth, 'jus sanguinis' gives recognition to blood ties. Citizenship is listed in the union list under the constitution and thus is under the exclusive jurisdiction of parliament. The constitution does not define the term 'citizen' but persons who are entitled to citizenship are given in part II (Article 5to11). Other provisions of the constitution, which came in to existence on $26^{\text {th }}$ January 1950 , these articles were enforced on $26^{\text {th }}$ November 1949 . Constitution of India provides certain privileges to the citizen of India. The Indian legislation related to this matter is 'The Citizenship Act, 1955' which has been amended by the Citizenship Amendment Act of 1986, 1992, 2003, 2005 and 2019. The aim of this essay is to find the answer of following questions, How to become Indian citizen?, What are the articles of the constitution which deals with citizenship?, What are the benefits of being a citizen?, What are the responsibilities that go along with citizenship?, What will happen to our rights and privileges if we don't meet those responsibilities?

\section{Citizenship of India and Constitutional Provisions}

Part II of the Indian constitution deals with citizenship and its provisions. Constitution of India provides certain privileges to the citizen of India. It implies that citizenship confers a statute on citizens and gives them a right to enjoy all civil and political rights. ${ }^{1}$ Article 5 to 8 of the Indian constitution deals with the citizenship of India in the commencement of the constitution. ${ }^{2}$ Article 9 to 11 deals with the modes of acquisition and loss of citizenship. Let's see, Articles of the constitution which deals with citizenship in detail, persons who acquired citizenship at the commencement of the constitution, by virtue of Article 5 to 11 can be divided in to the following categories, ${ }^{3}$ Article 5 provided for citizenship on commencement of the constitution. It says that certain conditions are to be a citizen of India they are, If he was born in India (OR) If either of his parents was born in the territory of India (OR) If he has been ordinarily a resident in the territory of India for not less than five year immediately preceding the commencement of the

\footnotetext{
${ }^{1}$ India Const.art. 5 to 8

${ }^{2}$ India Const.art.9 to 11

${ }^{3}$ INDIA CONST.art.5
}

constitution, shall be a citizen of India. In ${ }^{4}$ Abdul Samad v. State Of West Bengal (A. I. R 1973 S. C 505); it was held that domicile means the place which a person has fixed as a habitation for himself and his family not for a mere special and temporary purpose but with a permanent intention of making it his permanent home. The domicile can be three kinds they are, domicile by birth, domicile by dependence and domicile of choice.

${ }^{5}$ Article 6 provided rights of citizenship of certain persons who have migrated to India from Pakistan. Since independence was preceded by partition and migration, Article 6 laid down that anyone who migrated to India before $19^{\text {th }}$ July 1949 would automatically become an Indian citizen if either of his parents or grandparents was born in India. But those who entered India after this date needed to register themselves. ${ }^{6}$ Article 7 provided Rights of citizenship of certain migrants to Pakistan. Those who had migrated to Pakistan after $1^{\text {st }}$ March 1947 but subsequently returned on resettlement permits were included within the citizenship. The law was more sympathetic to those who migrated from Pakistan and called them refugees than to those who, in state of confusion, were stranded in Pakistan or went there but decided to return soon. ${ }^{7}$ Article 8 provided Right of citizenship of certain persons of Indian origin residing outside India. Any person of Indian origin residing outside India he, or either of his parents or grandparents, was born in India could register himself or herself as an Indian citizen with Indian Diplomatic Mission.

${ }^{8}$ Article 9 provided that no person shall be citizen of India, if he has voluntarily acquired the citizenship of any foreign state. ${ }^{9}$ Article 10 says that every person who is or is deemed to be a citizen of India under any of the foregoing provisions of this part shall, subjected to the provisions of any law that made by parliament continue to be such citizen. ${ }^{10}$ Article 11 empowers parliament to regulate the right of citizenship by law. Nothing in the foregoing provisions of this part shall derogate from the power of parliament to make any provision with respect to the acquisition and termination of citizenship and all other matters relating to citizenship. These are the Articles which deal with citizenship.

\footnotetext{
${ }^{4}$ Abdul Samad v. State of west Bengal, A.I.R. 1973 S.C. 505 (India)

${ }^{5}$ INDIA CONST.art.6

${ }^{6}$ INDIA CONST.art.7

${ }^{7}$ INDIA CONST.art.8

${ }^{8}$ INDIA CONST.art. 9

${ }^{9}$ INDIA CONST.art. 10

${ }^{10}$ INDIA CONST.art.11
} 


\section{Single Citizenship in India}

The Indian constitution provides for a single citizenship for the whole of India. The citizens of country belong to the Indian union and not to any respective states. One cannot be citizens of the state as well. This helps in increasing the feeling of nationality and encourages patriotism as it forges unity amidst regional and cultural differences. It also encourages fundamental rights such as the freedom of movement and residence in any part of the nation. Provision for single citizenship for the whole of India was conceivably intentional. The constitution fathers did not like that regionalism and other disintegrating tendencies which had already raised their ugly heads and were endangering the very security and integrity of the country, should be further encouraged by providing double citizenship. Provisions for double citizenship would normally stand on the way of emotional and national integration. The people in the state would have thought more in terms of the state than the country as a whole. Single citizenship has undoubtedly forged a sense of unity among the people of India and the image of united India reflected by this provision.

In other words, there is provision of single citizenship in India. A person may be living in any state, but he is the citizen of India alone. The principle of double citizenship promotes regionalism and provincialism whereas the principle of single citizenship promotes national unity, therefore the principle of single citizenship is adopted in India.

\section{Act and Amendments}

The Citizenship Act, 1955 provides for the acquisition and determination of Indian citizenship. Article 11 of the constitution empowers the parliament to make laws for acquisition of citizenship, after the commencement of the Indian constitution. Accordingly the parliament of India enacted the Citizenship Act, 1955. ${ }^{11}$ Sections 3 to 10 of the said Act deal with the problem of acquisition and termination of citizenship. Under the provision of this act, citizenship can be acquired in five ways that is Citizenship by birth; under ${ }^{12}$ section 3 of the Citizenship Act 1955 citizenship can only be acquired by such persons after the amendment of 1986 only if either of the parents is a citizen of India at the time of birth. After Citizenship Act 2003 both the parents are citizen of India or one of the parents is a citizen of India and other parent is not an illegal migrant at the time of his birth he can acquire citizenship by birth. Secondly, Citizenship by descent; According to ${ }^{13}$ section 4 of this Act, a person who was born on or after $26^{\text {th }}$ January 1950, outside India. But before 10th December 1992 shall be a citizen of India by descent, if either of his parents was a citizen of India at the time of birth of the person. ${ }^{14}$ Citizenship can also be acquired by registration (section 5); A person of Indian origin who has been a resident of India for 7 years before applying for registration. A person of

\footnotetext{
${ }^{11}$ Citizenship Act, 1955, $\S 3$ to 10 , Acts of parliament ,1955(India)

${ }^{12}$ Citizenship Act, 1955, $\S 3$, Acts of Parliament, 1955(India)

${ }^{13}$ Citizenship Act, 1955, $\$ 4$, Acts of Parliament, 1955(India)

${ }^{14}$ Citizenship Act,1955, §5 , Acts of Parliament,1955(India)
}

Indian origin who is a resident of any country outside undivided India. A person who is married to an Indian citizen and is ordinarily resident for 7 years before applying for registration. Minor children of persons who are citizens of India. ${ }^{15} \mathrm{~A}$ person can acquire citizenship by naturalisation (section 6) if he/she is ordinarily resident of India for 12 years and fulfils all qualifications in the third schedule of the Citizenship Act. The act does not provide dual citizenship or dual nationality. Lastly, citizenship can also acquired by incorporation of territory. ${ }^{16}$ According to section 7 of this act, if any territory becomes part of India person connected to that territory becomes citizen of India. An order in this regard has to be passed by the central government. No mention of persons required to make an application in this regard is there in the Act. It only allows citizenship for a person listed under the provisions above that is by birth, decent, registration or naturalisation, by incorporation of territory. Through these ways a person can become an Indian citizen.

Under the provision of Citizenship Act, $1955,{ }^{17}$ section 8 to 10 deals with the termination of citizenship. Citizenship can be terminated in any of the following three ways, (a) by renunciation (section 8), (b) Deprivation of citizenship (section 9), (c) by acquisition of Indian territory of another country (section 10).

The Citizenship Act, 1955 has been amended six times 1986, 1992, 2003, 2005, 2015 and 2019. Through these amendments parliament has narrowed down the wider and universal principles of citizenship based on the fact of birth Moreover, the Foreigners Act places a heavy burden on the individual to prove that he/she is not a foreigner. Let's see about the newly enacted ${ }^{18}$ Citizenship Amendment Act of 2019, the purpose of amendment is to permit members of six communities they are Hindus, Sikhs, Buddhists, Jains, Parsis and Christians from Pakistan, Bangladesh and Afghanistan to continue to live in India if they entered India before $14^{\text {th }}$ December 2014. It also reduces the requirement for citizenship from 11years to just 6 years. Two notifications also exempted these migrants from the Passport Act and Foreigners Act. A large number of organisations in Assam protested against this bill as it may grant citizenship to Bangladesh Hindu illegal migrants. The justification given for the bill is that Hindus and Buddhists are minorities in Bangladesh, and fled to India to avoid religious persecution, but Muslims are a majority in Bangladesh and so the same cannot be said about them.

\section{Fundamental Duty is Responsibility of Indian Citizen}

Fundamental duties were incorporated in the Indian constitution by $42^{\text {nd }}$ amendment. There are 11 fundamental duties for Indian citizens drafted on the lines of moral, ethical and culture code of conduct followed by people. The duties are educative in nature and direct the citizens to behave in a virtuous and honourable manner. However, by

\footnotetext{
${ }^{15}$ Citizenship Act, 1955, §6 ,Acts of Parliament, 1955(India)

${ }^{16}$ Citizenship Act, 1955, \$7 ,Acts of Parliament, 1955(India)

${ }^{17}$ Citizenship Act, 1955, $\S 8$ to $\$ 10$,Acts of Parliament, 1955(India)

18 Citizenship Amendment Act, 2019, Acts of Parliament 2019(India)
} 
the $86^{\text {th }}$ Amendment in 2002 , the original 10 duties were then increased to 11 , under ${ }^{19}$ Article $51 \mathrm{~A}$, Part IV A of the constitution of India. The 10 fundamental duties are as follows:

- To abide by the constitution and respect its ideals and institutions, the National flag and National Anthem.

- To cherish and follow the noble ideals which inspired our national struggle for freedom.

- To uphold and protect the sovereignty, unity and integrity of India

- To defend the country and perform national services if and when the country requires

- To promote the spirit of harmony and brotherhood amongst all the people of India and renounce any practices that are derogatory to women

- To cherish and preserve the rich national heritage of our composite culture

- To protect and improve the natural environment including lakes, wildlife, rivers, forests etc.

- To develop scientific temper, humanism, and spirit of inquiry

- To safeguard all public property

- To strive towards excellence in all genres of individual and collective activities.

The $11^{\text {th }}$ fundamental duty which was added to this list is:

- To provide opportunities for education to children between 6 - 14 years of age, and duty as parents to ensure that such opportunities are being awarded to their child.

The 11 fundamental duties look at the crisis in Indian society and become a tool for straightening it out. They serve as a source of protection for the liberty of the people. It is a citizen's responsibility to realize that it is in their own interest to perform their duties and discharge their legal and constitutional obligations whole - heartedly because only by doing so, individually, can they help the growth of the democratic republic collectively. In the landmark judgement of the ${ }^{20}$ KesavanandaBharati v. State of Kerala, The Apex Court has referred to the Fundamental Duties as an element to justify the Constitutional principles of laws and policies aiming to elevate the objects laid out under the section of Fundamental Duties. These duties have been referred to as an imperative part of all citizens' conduct.

Every responsible citizen of India must know the fundamental duties provided by the Constitution. This unrestricted nature of these duties paved way for the observance or ignorance. Thus the fundamental duties become a mere obligation. The constitution of India provides some fundamental rights and duties in the Part III and Part IV A. An Individual should know that rights and duties cannot go separate. To ensure one's claim towards the fundamental duties followed by that person will be checked before the court of law. Failure of performance of duty the person claims for his/her fundamental rights becomes invalid. As an instant remainder to the citizens fundamental duty is necessary. This should be realized by every citizen of the state. We people are the state and the state is by the

\footnotetext{
${ }^{19}$ INDIA. CONST. art 51A

${ }^{20}$ Keshavnanda Bharti v. State of Kerala, (1973) 4 SCC 225 (India)
}

people. Every responsible individual must understand the need to follow the fundamental duties to attain unity and to develop the integrity of the nation. The fundamental duties serve as a reminder to citizens that while enjoying their rights, they have also to be quite conscious of duties they owe to their country, their society and to fellow citizens." The price of greatness is responsibility", let us keep in mind these words spoken by Vincent Churchill.

\section{Fundamental Rights of Citizen}

The Constitution of India guarantees six fundamental rights to Indian citizens they are, right to equality, right to freedom, right against exploitation, right to freedom of religion, cultural and educational rights, and right to constitutional remedies. Article 14 to 18 deals with Right to equality. ${ }^{21}$ Article 14 deals with Equality before law and equal protection of laws. ${ }^{22}$ Article 15 deals with Prohibition of discrimination on grounds of religion, race, caste, sex or place of birth and equal access to shops, hotels, wells, tanks, roads etc. ${ }^{23}$ Article 16 deals with Equality of opportunity in public employment. ${ }^{24}$ Article 17 deals with Abolition of Untouchability. ${ }^{25}$ Article 18 deals with Abolition of titles Article 19 to 22 deals with Right to freedom. ${ }^{26}$ Article 19 provides protection of rights to freedom of speech and expression, Assemble peacefully without arms, right to form associations or unions or co - operative societies, right to move freely throughout the territory of India, right to reside and settle in any part of the territory of India, right to practice any profession or to carry on any occupation, trade or business. ${ }^{27}$ Article 20 grants protection against arbitrary and excessive punishment to an accused person. ${ }^{28}$ Article 21 guarantees Right to life and personal liberty. ${ }^{29}$ Article $21 \mathrm{~A}$ gives Right to education. The provision was added by 86 th Constitutional Amendment Act of 2002. ${ }^{30}$ Article 22 grants protection to persons who arrested or detained. The Article 23 and 24 guarantees the right against Exploitation. ${ }^{31}$ Article 23 of the constitution prohibits human trafficking and forced labour to protect the millions of underprivileged and deprived people of the country. The right is available to citizens of India as well as to non - citizens. ${ }^{32}$ Article 24 of the Indian constitution forbids employment of children below the age of 14 years in dangerous jobs like factories and mines.

Article 25 to 28 deals with right to freedom of religion. ${ }^{33}$ Article 25 of the constitution of India provides the freedom of conscience, to profess, to practice and to propagate any religion. These rights are available to citizens as well as non

\footnotetext{
${ }^{21}$ INDIA CONST. art.14

${ }^{22}$ INDIA CONST. art.15

${ }^{23}$ INDIA CONST. art.16

${ }^{24}$ INDIA CONST. art.17

${ }^{25}$ INDIA CONST. art. 18

${ }^{26}$ INDIA CONST. art.19

${ }^{27}$ INDIA CONST. art.20

${ }^{28}$ INDIA CONST. art. 21

${ }^{29}$ INDIA CONST. art.21A

${ }^{30}$ INDIA CONST. art.22

${ }^{31}$ INDIA CONST. art. 23

${ }^{32}$ INDIA CONST. art.24

${ }^{33}$ INDIA CONST. art. 25
} 
- citizens. ${ }^{34}$ Article 26 of the Indian constitution provides every religious denomination. The right to establish and maintain institutions for religious and charitable purposes. .

${ }^{35}$ Article 27 lies down that no person shall be compelled to pay any taxes for the promotion or maintenance of any particular religion. ${ }^{36}$ Article 28 states that no religious instruction shall be provided in any religious instruction wholly maintained out of state funds. Article 29 and 30 deals with cultural and educational right. ${ }^{37}$ Article 29 grants protection to both religious, linguistic as well as cultural minorities. ${ }^{38}$ Article 30 grants minorities to establish and administer educational institutions. ${ }^{39}$ Article 32 of the Indian consitution deals with constitutional Remedies. The framers of the constitution incorporated the real rights. They have also provided effective remedies for the enforcement of right under Article 32. ${ }^{40}$ Article 226 also empowers the high court to issue the writs for the enforcement of fundamental rights. The writ in nature of Habeas corpus, Mandamus, Prohibition, Quo warranto, Certiorari. Whatever may be appropriate for the enforcement of rights under part III. Fundamental right play a very significant role in the life of any citizen. These rights can defend during the time of complexity and difficulty and help us grow into good human being and that's why all the rights are needs of people.

\section{Benefits of being An Indian Citizen}

There are some real benefits of Indian citizenship they are;

- You get free health insurance from government in some states to just get into any private hospital and treated for free. It's called Arogyasree in telangana state. It's privilege entitled only to eligible citizens of India.

- Subsidized grains, serials, groceries and consumables at certain government outlets on submission of a certain coloured ration card and entitled only for citizens

- If you are a patient with rare genetical disorder, let's say -haemophilia. You need highly expensive injections to keep you healthy and alive. Rush to a government hospital and the injection is for free.

- Vaccinations are free and expensive ones are heavily subsidized in government hospitals. The qualities are perfect.

- Access to free treatment in any government hospital.

- Access to subsidized high quality education in any government runs schools.

- Access to free education in private schools

- Access to free electricity if you are a farmer.

- Access to 20000 litters of free water for domestic use if you are a citizen and it's only in some states.

- If you are economically backward families, if a girl gets married, there is a decent amount of cash remittance into the individual's account for wedding expenses in certain states.

\footnotetext{
${ }^{34}$ INDIA CONST. art.26

${ }^{35}$ INDIA CONST. art.27

${ }^{36}$ INDIA CONST. art.28

${ }^{37}$ INDIA CONST. art.29

${ }^{38}$ INDIA CONST. art. 30

${ }^{39}$ INDIA CONST. art.32
}

- Pregnant women get some kits with medicines and healthcare consumables and some cash for appointments and personal nourishment in some states.

- Subsidy on LPG gas for everyone.

- The income taxes are low compared to many countries in the world.

- No tax on rented house

- Only 5\% tax if you eat in a restaurant.

- Certain governments distribute free laptops, sports gears, and many necessary things to the economically backward youth.

- Government jobs have decent pension post retirement with healthcare coverage for fewer premiums.

- Low tourist entry fees for citizens to world heritage sites visit.

- Significant contribution to the country in any field cam entitles you to various awards and titles, some of which considered a true honour.

- If you are economically backward, you are reserved for some benefits like higher age limit for both jobs and education and lower cut off on scores in entrance. examinations or interviews

- Excellent help from government to citizens if you are going to initiate a start - up. Each state has its own attractive schemes.

- Subsidised interest rates for senior citizens on bank loan. And in some states, for women entrepreneurs too.

- Monthly payment of some cash amount, which can cover medicines or some very basic expenses to handicapped and unemployed senior citizens from economically backward families.

The list goes on and on.

India does have its own demerits like every other country, and lacks behind in lot many things like many other countries, but India is part of so many top ten lists and it makes it a very strong economy, a strong military, safe, peaceful and prosperous with a great potential and future.

\section{Conclusion}

Citizenship is relationship between an individual and a state to which the individual owes allegiance and in turn is entitled to its protection. Citizenship implies the status of freedom with accompanying responsibilities. This essay set out to understand the importance of citizenship as a citizen. It is my wish that every citizen must follow the fundamental duties for inculcates a sense of social responsibility. If the all ministers of respective state serve the nation without corruption the rights of every citizen will not be hindered. A government that denies rights is the curse of the country. A government order is to implement equal justice for all citizens and it is the responsibility of the every citizen to understand their rights as well as their duties provided in Indian constitution. "The youth who have the guts to change will wake up, when you wake up, India will wake up and the chains of slavery will break". 